\title{
PHENOTYPIC AND GENOTYPIC PERFORMANCES OF BLACK TIGER SHRIMP, Penaeus monodon HAVING FAST GROWTH TRAITS
}

\author{
Haryanti \#, Ahmad Muzaki, Ida Komang Wardana, Fachrudin, \\ Sari Budi Moria, and I Gusti Ngurah Permana \\ Research Institute for Mariculture \\ PO Box 140 Singaraja 81101 -Bali
}

\begin{abstract}
Shrimp breeding research focusing on fast growth traits is important to develop better phenotypic and genotypic characters of shrimp spawners. The aim of this research was to evaluate shrimp breeding technology to produce fry having fast growth traits. Selection was initiated from the breeding of wild shrimp spawners (F-0) based on full sib mating, probiotics, biosecurity, and viral diseases diagnosis. Viral disease diagnoses were performed using 7 viruses (TSV, WSSV, IHHNV, YHV, BP, MBV, and HPV) provided in the IQ-2000 kit. The result showed that 11 families of the first generation ( $\mathrm{F}-1$ ) shrimp were phenotypically varied (big, regular and small size). Number of fry from the first generation resulted from phenotypic selection that have fast growth trait ranged between $1.99 \%$ and $4.49 \%$ of the total fry population. Genotypic performance of the shrimp broodstock ( $\mathrm{F}-0)$ and the first generation (F-1) showed different genetic variations. Heterozigosity values were $0.2872 \pm 0.0047$ (female) and $0.5487 \pm 0.0103$ (male) for shrimp broodstock (F-0), $0.704 \pm 0.0261$ for the first generation (F-1) having fast growth trait, and $0.6224 \pm 0.023$ for F-1 having slow growth. Gene markers of fast growth trait were indicated by the genes with molecular weights of 1,$025 ; 1,280$; and 1,325 basepairs and having different DNA sequences compared to that of slow growth shrimp.
\end{abstract}

KEYWORDS: breeding, fast growth, phenotype, genotype, Penaeus monodon

\section{INTRODUCTION}

Black tiger shrimp Penaeus monodon has been commercially cultured for decades and developed as one of the prominent aquaculture commodities to support Indonesian growing economy. In general, most of black tiger shrimp fry stocked in culture ponds, are supplied from hatcheries that use broodstock caught from wild population (Ahmad \& Haryanti, 2004; Ahmad et al., 2004). However, steadily decline of black tiger shrimp productivity in pond caused by infectious diseases, virus in particular has made the business decreased to a very low point and most of fish farmers have switched to Litopenaeus vannamei shrimp culture. It was widely known that the broodstock of L. vannamei were produced from breeding selection program and imported from the USA. With the limitation of genetic characters of the shrimp, it is difficult to develop the progeny for a long period of time, and therefore, imported broodstock demand is very high. The following impact of this practice is that a significant amount of capital and investment flows out from Indonesia.

\# Corresponding author. Research Institute for Mariculture. Jl. Br. Gondol, Kec. Gerokgak, Kab. Buleleng, Kotak Pos 140, Singaraja, Bali 811 101, Indonesia. Tel.: (0362) 92278, Fax. (0362) 92272/71 E-mail address: haryanti@indosat.net.id 
In order to successfully recover black tiger shrimp culture, continuous improvement, effective anticipation, and prevention of failure factors should be carried out thoroughly and consistently. One of the aspects that needs more attention is the study of genetic characters of black tiger shrimp. This has to be started with mapping of genetic variations and populations of black tiger shrimp in Indonesian waters (Benzie et al., 2002; Sugama 2002), domestication of shrimp broodstock collected from different waters regions through breeding and evaluation of their progeny (Moria et al., 2002; Moria et al., 2003), and selective breeding based on both phynotypic and genotypic performances of black tiger shrimp (Haryanti et al., 2007; Haryanti \& Sugama, 2007).

Since 2005, the Research Institute for Mariculture, Gondol, Bali has been conducting well directed and systematic researches on breeding selection of black tiger shrimp from the nature (F-0) and its first generation (F-1). The result of breeding selection of wild black tiger shrimp broodstock ( $F-0$ ) collected from Timika and Aceh waters and their first generation ( $\mathrm{F}-1)$ was that 19 prospective families of shrimp broodstock have been obtained, and showed various rates of growth. Based on the result reported by Benzie et al. (1997), it was proved that genetic variation strongly influenced the quality of the larvae of $P$. monodon, while the growth was controlled by genetic factor. Therefore, the role of genetic factor in breeding is important in order to obtain high quality shrimp broodstock and fry. Sbordoni et al. (1987) also stated the important of genetic variation for continuous culture stock production of Penaeid shrimp ( $P$. japonicus) which was showed by a strong relationship between decreasing productivity of broodstock and the variability of growth.

Research on breeding selection with the main focus on growth character and disease free (Specific Pathogen Free/SPF) is the main important aspect to produce shrimp broodstock with better phenotypic and genotypic characters. From the result of this research, it is hoped that shrimp practitioners can be motivated and expected to re-use black tiger shrimp as a still prospective species in their shrimp culture business. The other benefit is to provide the industry, in commercial scale hatchery, with the supply of best quality of fry for pond culture.

\section{MATERIAL AND METHOD}

The first step of breeding selection is breeding of wild shrimp ( $\mathrm{F}-\mathrm{O})$ to provide broodstock candidate (F-1). Breeding refer to the principle of full sib matting with the ratio of male:female of $1: 1$ in order to obtain fry with different family. The technique of breeding must follow the available method such as gonadal maturation through eye stalk ablation, maintaining larvae by giving natural and artificial feeds, water quality management with probiotic application, and observation of diseases and bio-security application. Biosecurity system that was applied in each rearing step included sterilization of equipment, use of filtered sea water through ultra membrane $(0.05 \mu \mathrm{m})$ filter, desinfection of technician and hatchery.

Evaluation of SPF trait of wild shrimp broodstock ( $F-0)$ used for the breeding process was carried out by challenging them to 7 virus infection category tests such as C-1 and C-2, i.e. TSV, WSSV, IHHNV, YHV, BP, MBV, and HPV using IQ-2000 kit. The test result will classify the SPF trait of shrimp broodstock. The suspected infected shrimp by one of the viruses or more has to be discharged and could not be used for breeding. Only shrimps showing negative virus infection were chosen for breeding process and used for further research.

Shrimp fry produced from the breeding was classified as the first generation ( $\mathrm{F}-1)$ and reared to reach the right size as broodstock candidate. Shrimp fry selection was carried out in the second month of rearing period. Shrimp fry were selected based on their morphological appearances and health conditions such as clean, having bright color and normal swimming activity and growth variability in terms of different sizes (big, medium, and small). At the beginning of the fifth month of rearing period, selected shrimp juveniles were tagged using VIE (Visible Implants of Fluorescent Elastomer) following the method of Goyard et al. (2002).

Phenotypic character analysis of the shrimp fry was carried out by measuring body length and weight, size, survival rate, and monitoring of SPF trait from the beginning up to the fry reaching the size as broodstock candidate (F-1). While genotypic character analysis was carried out by DNA isolation from the broodstock (F-0) and first generation ( $\mathrm{F}-1)$ 
following growth variation method by Ovenden (2000), PCR amplification with universal primer and SSCP (Single Strand Conformation Polymorphism) method to identify genetic variation of shrimp stock (F-0), F-1 (big, medium, small) suggested by Anonimous (2001), and DNA fragmentation with fingerprinting method using polyacrylamide and vertical electrophoresis for broodstock candidate ( $F-1)$ in different sizes (big, medium, small) in order to identify growth gene marker (Flegel 2007). TFPGA (Tool For Population Genetic Analysis) was used in data calculation.

\section{RESULT AND DISCUSSION}

\section{Phenotypic Performance}

The treeding experiment used wild female shrimp broodstock (F-0) collected from Aceh waters sized of $24.2-30.7 \mathrm{~cm}$ in length and $139.5-269.7 \mathrm{~g}$ in weight, and male shrimp broodstock of $21.2-22.0 \mathrm{~cm}$ in length and 82.0$89.0 \mathrm{~g}$ in weight. After ablation procedure, almost all of shrimp broodstock showed gonadal maturation, although not all of them spawned and produced eggs and hatched out. Shrimp broodstock often did not spawn and the gonad was reabsorbed or the broodstock spawned partially producing either less number of eggs $(<50,000$ eggs $)$, infertile or undeveloped eggs.

It could be seen from the breeding process that 11 black tiger shrimp broodstock were able to produce the first generation of fry $(\mathrm{F}-1)$ with good phenotypic characters and then reared as the candidates of future broodstocks. In general, female and male shrimp broodstock were captured from the sea in 20-40 m depth, and might be possible to have homogeny phenotypic performance (length and weight). Beside that, natural selection also influences on phenotypic performance of fish.

Observation on egg fecundity, hatching rate and survival rate of shrimp larvae at PL-12 showed variations among bred broodstocks of P. monodon. The average of egg fecundity was 194.680-642.400 eggs with hatching rate of $9,4 \%-98,7 \%$ and survival rate larvae on PL-12 of $2.30 \%-46,35 \%$ (Table 1). Egg fecundity of panaeid shrimp was strongly influenced by nutrition, environment condition and hormonal processes inside shrimp body. The shrimp broodstock supplied with good and balanced nutrition in ambient environment will produce high egg fecundity. Furthermore, hatching rate of egg is strongly influenced by embryonic development inside the egg, the availability of energy for normal division of embryonic cell, and bacteria free infection on cell wall.

In general, survival rate of shrimp larvae has a close relationship with rearing process. Handling of larvae with probiotic application, clean natural feeds, use of filtered sea water, and tight biosecurity will result in higher survival rate. Shrimp larvae at zoea, mysis, and PL-1 to PL-5 stadia are very susceptible to

Table 1. Levels of fecundity, hatching rate, and survival rate of black tiger shrimp $P$. monodon $\mathrm{F}-1$ used in the selective breeding

\begin{tabular}{|c|c|c|c|}
\hline Spawner & $\begin{array}{l}\text { Fecundity } \\
\text { (pcs) }\end{array}$ & $\begin{array}{c}\text { Hatching rate } \\
\text { (\%) }\end{array}$ & $\begin{array}{c}\text { Survival rate } \\
(P L-12)(\%)\end{array}$ \\
\hline ㅇ -1 & 640,800 & 44.4 & 46.35 \\
\hline 우 -3 & 435,900 & 9.4 & 2.3 \\
\hline 우 -5 & 331,200 & 98.7 & 29.65 \\
\hline$q-6$ & 458,400 & 55 & 40.9 \\
\hline ㅇ -11 & 585,194 & 25 & 10.9 \\
\hline$q-15$ & 484,800 & 33.2 & 17.5 \\
\hline 우 -17 & 256,800 & 84.6 & 12.9 \\
\hline o -18 & 642,400 & 62.7 & 16.7 \\
\hline$q-26$ & 552,000 & 79.4 & 37.3 \\
\hline 우 -28 & 194,680 & 12 & 6.95 \\
\hline$q-30$ & 413,300 & 49 & 12.9 \\
\hline
\end{tabular}


any of environmental changes such as temperature, bacteria infection (luminescent bacteria, Vibrio harveyi) and the quality of natural or artificial feeds. Temperature fluctuation of $1^{\circ} \mathrm{C}-2^{\circ} \mathrm{C}$ will change larval rearing water quality as indicated by low feeding activity of larvae, blooming or sedimentation of plankton and fluctuation of other water parameters. Weakening larvae, occurrence of secondary bacteria infection, and higher larval mortality are expected in such condition.

The analysis of SPF character of wild black tiger shrimp broodstock ( $F-0)$ at the time of breeding, after spawning and first generation of fry (F-1) showed negative infection of 7 viruses ( BP, HPV, IHHNV, MBV, TSV, WSSV, and YHV). Regular observation on virus infection were regularly conducted to keep the SPF character during the breeding selection.

SPF character of black tiger shrimp (F-0) becomes the main priority to obtain next generations with the same SPF characters. Virus infection could occur vertically or horizontally. Therefore, prevention through diagnosis of any virus infection should be performed as early as possible (Lightner 2004).

Based on phenotypic selection on shrimp fry of the first generation ( $F-1)$, the percentage of populations classified in terms of size (big, medium, and small) after the first two months of rearing period were varied. Shrimp fry with normal growth (medium size) had a relatively high population percentage. The difference of growth among the first generation populations ( $\mathrm{F}-1)$ is provided in Table 2.

Table 2. Population and percentage of the first generation ( $F-1)$ fry of black tiger shrimp ( $P$. monodon) with different growth sizes produced from the selective breeding

\begin{tabular}{|c|c|c|c|}
\hline \multirow{2}{*}{ Spawner } & \multicolumn{3}{|c|}{$\begin{array}{c}\text { Selection number (pcs) and } \\
\text { percentage (\%) }\end{array}$} \\
\hline & big & regular & small \\
\hline \multirow{2}{*}{ 우 -1 } & 129 & 2786 & 2667 \\
\hline & (2.31\%) & (54.76\%) & (42.48\%) \\
\hline \multirow{2}{*}{ q -3} & 52 & 957 & 297 \\
\hline & (3.98\%) & (73.28\%) & (22.74\%) \\
\hline \multirow{2}{*}{ 우 -5} & 328 & 3647 & 3327 \\
\hline & $(4,49 \%)$ & (49.945\%) & (45.56\%) \\
\hline \multirow{2}{*}{ 우 -6 } & 431 & 5767 & 9229 \\
\hline & $(2,79 \%)$ & (37.38\%) & (59.82\%) \\
\hline \multirow{2}{*}{ 우 -11} & 52 & 544 & 1063 \\
\hline & (3.13\%) & (32.79\%) & (64.07\%) \\
\hline \multirow{2}{*}{ 우 -15 } & 170 & 2699 & 335 \\
\hline & (5.3\%) & (84.24\%) & (10.455\%) \\
\hline \multirow{2}{*}{ q -17 } & 432 & 5426 & 4579 \\
\hline & (4.14\%) & (51.99\%) & (43.87\%) \\
\hline \multirow{2}{*}{ q -18} & 183 & 1585 & 6142 \\
\hline & (2.31\%) & (20.04\%) & (77.65\%) \\
\hline \multirow{2}{*}{ 우 -26 } & 148 & 1965 & 3720 \\
\hline & (2.54\%) & (33.69\%) & (63.77\%) \\
\hline \multirow{2}{*}{ 우 -28} & 22 & 445 & 479 \\
\hline & $(2.32 \%)$ & (47.04\%) & (50.63\%) \\
\hline \multirow{2}{*}{ ㅇ-30 } & 55 & 1161 & 1551 \\
\hline & (1.99\%) & (41.96\%) & (56.05\%) \\
\hline Total & $\begin{array}{c}2002 \\
(3.21 \%)\end{array}$ & $\begin{array}{l}26982 \\
(43.26 \%)\end{array}$ & $\begin{array}{c}33389 \\
(53.53 \%)\end{array}$ \\
\hline
\end{tabular}


It is clear that there is growth difference among the first generation ( $F-1$ ) fry, while the condition of reared larvae was the same as the control. This results showed a tendency that conventional selection based on phenotypic character (big size and fast grow) could be used as genotypic indicator of shrimp. Based on genetic phenomena, Ramirez (1991) stated the value of $\Delta \mathrm{P}=\Delta \mathrm{G}+\Delta \mathrm{E}(\Delta \mathrm{P}$ : coefficient variation phenotype, $\Delta \mathrm{G}$ : coefficient variation genotype and $\Delta \mathrm{E}$ : coefficient variation of environment). When it was assumed that first generation ( $F-1)$ fry were reared in the same environment, then $\Delta \mathrm{E}=0$, which means that $\Delta \mathrm{P}=\Delta \mathrm{G}$ (phenotype character $=$ genotype character). In other words, shrimp that grows fast (big size) is highly possible to have better genotypic character.

Table 2 shows that shrimp populations at juvenile stadium indicating fast grow traits were relatively very low, only $2,31 \%-5,30 \%$, while shrimps having slow grow traits were $10,45 \%$ $77,65 \%$ and shrimps with normal grow were $32,79 \%-84,24 \%$. Based on the fact that shrimps with fast grow is usually low in number, breeding selection has to be done in a large number of broodstock in order to obtain more fast grow family shrimps. During the selection of the first generation, cultured shrimp juveniles should be observed very often, mostly on their SPF character testing, growth and also VIE tagging. The tag was implanted on the muscle surface of the shrimps and could stay there for a certain period of time until the shrimp have performed more than 30 times of moulting (Goyard et al., 2002). The presence of fluorescent color make it easy in observing the growth and sampling for viral diagnosis on each next progeny of black tiger shrimp.

Observation on the weight gain of each fry from breeding selection in a time interval is presented in Figure 1. It can be seen that the candidate of shrimp broodstock of the first generation ( $\mathrm{F}-1)$ from progeny parents 이 1,5 , $6,15,18,26$, and 30 showed very fast growth compared to the other broodstock candidates. This relates to the percentage of selection result obtained at the beginning of the selection. Shrimp broodstock encoded o-1, 5, $6,15,18,26$, and 30 gave the percentage of fast grow of $2.31 \%$; $4.49 \% ; 2.79 \% ; 5.30 \% ; 2.31 \%$; $2.54 \%$; and $1.99 \%$, respectively within population reared in the same tank. Using phenotypic performance indicator, represented by high percentage of fast grow, it can be seen the trend that the first generation (F-1) has a potential to carry fast grow genotypic trait.

The growth of selected broodstock candidates was increased sharply at beginning of the $4^{\text {th }}$ month of culture. It might relate to the selection conducted regularly, less density of shrimp population, and therefore reducing the competition among shrimps on feed, space and environment.

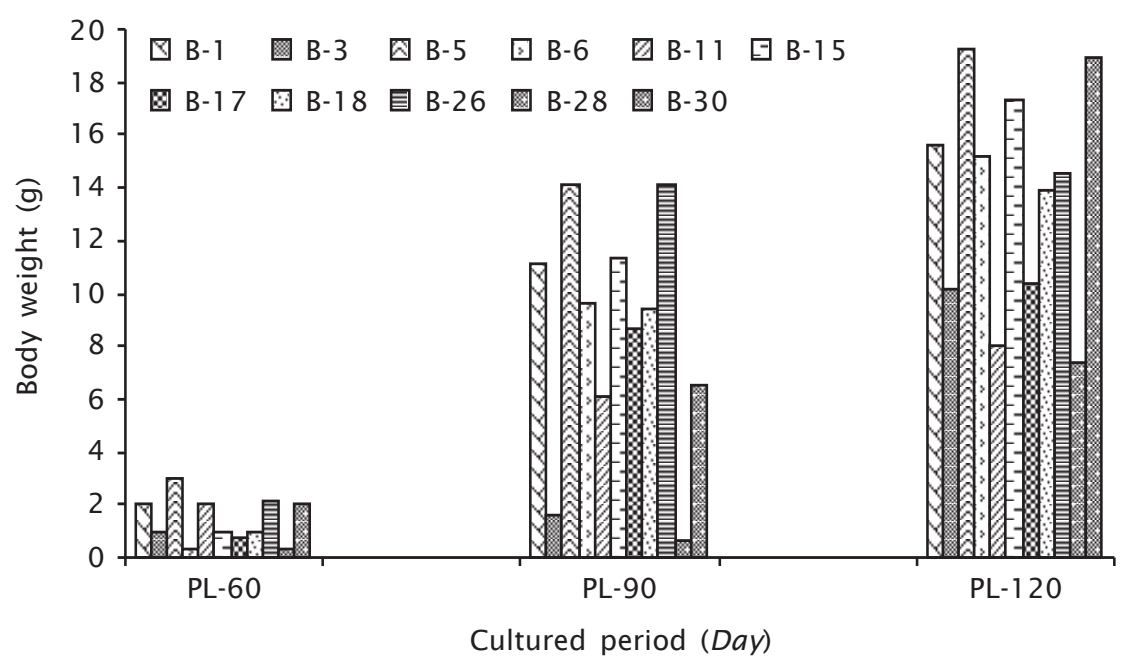

Figure 1. Growth pattern of the first generation F-1 of black tiger shrimp (P. monodon) produced from selective breeding 


\section{Genotype Performance}

DNA analysis of male and female shrimp broodstock (F-0) with 2AAM2 primer and amplification using speedy PCR expressed different polymorphism. The first generation (F-1) analyzed with PCR amplification and DNA fragmentation using SSCP also showed different polymorphism DNA among fry populations having fast, regular and slow growths. It showed that the male shrimp genotypes ( $\mathrm{F}-0$ ) were more varied with heterozygocity value of 0.6091 , while the female shrimp genotypes ( $F-0)$ tended to have less variation with heterozygocity value of 0.2872 (Table 3 ).

From heterozygocity calculation, it could be seen that big size fry (fast growth) in the first generation of shrimp ( $\mathrm{F}-1)$ possesed high value $(0,6633)$ while $F-1$ medium and small size shrimp fry possesed 0.6627 and 0.5512 , respectively. Heterozygocity value of the first shrimp generation was higher than that of wild shrimp broodstock ( $\mathrm{F}-0$ ) which is possible to make gene segregation in F-1 progeny. Shrimp breeding was conducted in mass and random mating. Therefore, there was a chance that male and female shrimp broodstock with high variation in genotype mated, and produced more varied heterozygous shrimp progeny. In this case, the first generation of shrimp fry (F-1) will have better genetic variation or at least similar to that of shrimp broodstock (F-0).

Table 3 shows Heterozygocity of the first generation fry (F-1) where fast, regular and slow growth populations are not significantly different. In addition, there is a possibility of dominant gene flow from male broodstock since the male broodstock has higher Heterozygocity value than that of female broodstock. Therefore, female genotypes of broodstock (F-0) and F-1 fry having fast growth traits were more varied than that of male broodstock (F-0) and F-1 fry from regular and slow growth populations.

Recognizing the difference in SSCP analysis, the investigation was continued to fingerprinting method using 8 samples of the first generation of fry (F-1) with fast and slow growth. PCR amplification was performed with universal primer (2-AAM2) and DNA template fragmentation using vertical electrophoresis with $8 \%$ of polyacrylamide. The expressed different bands caused by polyacrylamide fragmentation were then cut and transformed (cloned) to obtain DNA gene copy using $\mathrm{DH} 5 \alpha$.

Table 3. Genotypic and allel frequencies at loci detected in P. monodon broodstock (F-0) and the first generation of fry produced from the selective breeding

\begin{tabular}{|c|c|c|c|c|c|c|c|}
\hline \multirow{2}{*}{$\begin{array}{c}\text { Shrimp } \\
\text { generation }\end{array}$} & \multirow{2}{*}{$\mathbf{N}$} & \multirow{2}{*}{ Genotype } & \multicolumn{4}{|c|}{ Allel frequency } & \multirow{2}{*}{ Heterozigocity } \\
\hline & & & B & C & D & $\mathrm{E}$ & \\
\hline \multirow{3}{*}{ F-0 male } & 14 & $B$ & 0.5185 & 0.000 & 0.000 & 0.000 & \multirow{3}{*}{0.609} \\
\hline & 8 & $\mathrm{C}$ & 0.000 & 0.2963 & 0.000 & 0.000 & \\
\hline & 5 & $\mathrm{D}$ & 0.000 & 0.000 & 0.1852 & 0.000 & \\
\hline \multirow{4}{*}{$\mathrm{F}-0$ female } & 1 & B & 0.0323 & 0.000 & 0.000 & 0.000 & \multirow{4}{*}{0.287} \\
\hline & 26 & $\mathrm{C}$ & 0.000 & 0.8387 & 0.000 & 0.000 & \\
\hline & 2 & $\mathrm{D}$ & 0.000 & 0.000 & 0.065 & 0.000 & \\
\hline & 2 & $\mathrm{E}$ & 0.000 & 0.000 & 0.000 & 0.0645 & \\
\hline \multirow{4}{*}{ F-1 big size } & 5 & B & 0.3571 & 0.000 & 0.000 & 0.000 & \multirow{4}{*}{0.663} \\
\hline & 1 & $\mathrm{C}$ & 0.000 & 0.0714 & 0.000 & 0.000 & \\
\hline & 6 & $\mathrm{D}$ & 0.000 & 0.000 & 0.4286 & 0.000 & \\
\hline & 2 & $\mathrm{E}$ & 0.000 & 0.000 & 0.000 & 0.1429 & \\
\hline \multirow{3}{*}{$\mathrm{F}-1$ medium size } & 4 & $\mathrm{C}$ & 0.000 & 0.3077 & 0.000 & 0.000 & \multirow{3}{*}{0.663} \\
\hline & 5 & D & 0.000 & 0.000 & 0.3846 & 0.000 & \\
\hline & 4 & E & 0.000 & 0.000 & 0.000 & 0.3077 & \\
\hline \multirow{3}{*}{ F-1 small size } & 1 & $\mathrm{C}$ & 0.0714 & 0.000 & 0.000 & 0.000 & \multirow{3}{*}{0.551} \\
\hline & 6 & $\mathrm{D}$ & 0.000 & 0.4286 & 0.000 & 0.000 & \\
\hline & 7 & $\mathrm{E}$ & 0.000 & 0.000 & 0.500 & 0.000 & \\
\hline
\end{tabular}


$\begin{array}{lllllllllllll}M & 1 & 2 & 3 & 4 & 5 & 6 & 7 & 8 & 9 & 10 & 11\end{array}$

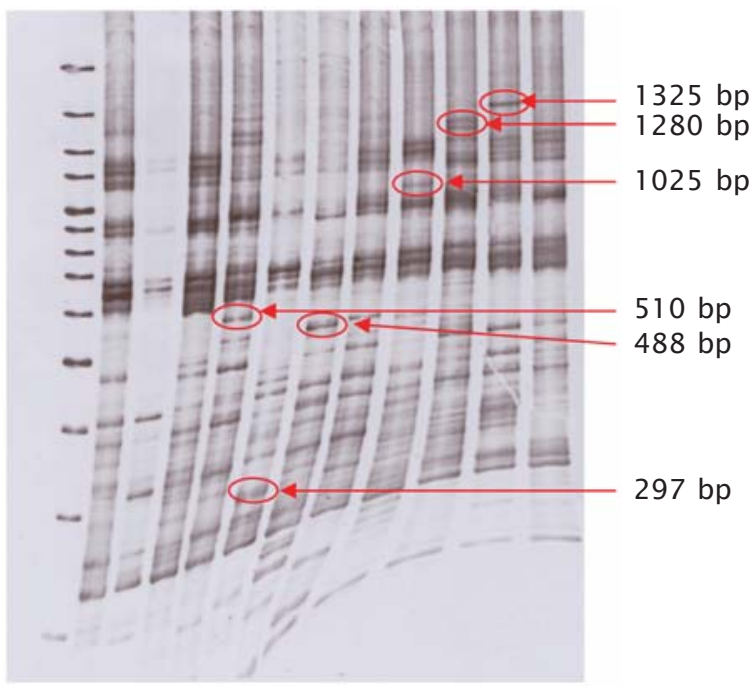

Figure 2. DNA Genotyping of the first generation (F1) fry of black tiger shrimp P.monodon with phenotypic traits of fast (7-11) and slow growth (1-6) M using fingerprinting method : marker gene ruler 100 bp DNA ladder plus

E. coli bacteria as a competent cell followed by DNA sequencing. The result obtained is shown in Figure 2. It can be seen that the DNA fragment of the fast growth shrimps has both large number of molecules and high molecular weight compared to the DNA fragment of slow growth shrimps. Molecular weights on fast growth shrimps were $1,025,1,280,1,325 \mathrm{bp}$, while slow growth shrimp were 297,488 , and $510 \mathrm{bp}$. After clustering, some base pairs could not be seen from the slow growth shrimps.

\section{CONCLUSION}

- Breeding selection of black tiger shrimp ( $P$. monodon) from wild shrimp broodstock (F0) produced 11 first generation fry (F1) families with phenotypic performance of fast grow and SPF. The average length of fry was $11.18 \mathrm{~cm}$ and body weight of 13.70 g.

- Genotypic performance of wild shrimp broodstock (F-0) of male and female have Heterozygocity of 0.6091 and 0.2872 , respectively. First generation of fry (F-1) with fast, regular, and slow growth had Heterozygocity of $0.6633,0.6627$, and 0.5612 , respectively.
- Gene marker in the fast growth shrimps analyzed using fingerprinting showed gene molecule weight of 1025, 1280 and 1325 base pair and the DNA formation sequence is different compared to the gene marker of slow growth shrimps.

\section{ACKNOWLEDGEMENT}

The author would like to thank all technicians of the Biotechnology laboratory, Research Institute for Mariculture for their assistance and support during and after the experiment. The research was funded through APBN 2008 of the Agency for Marine and Fisheries Research, Ministry of Marine Affairs and Fisheries the Republic of Indonesia.

\section{REFERENCES}

Ahmad, T. \& Haryanti. 2004. Policy Analysis of pond revitalitation in North offshore of East Java in Policy Analysis of Aquaculture Development (Eds by Sudradjat, Heruwati, Priono) Ministry of Marine Affairs and Fisheries Department. Jakarta (In Indonesia). p. 43-49.

Ahmad, T., Haryanti, Sutarmat, T., \& Muhari. 2004. Policy Analysis of black tiger shrimp 
broodstock trade for aquaculture. in Policy Analysis of Aquaculture Development (Eds by Sudradjat, Heruwati, Priono) Ministry of Marine Affairs and Fisheries Department. Jakarta (In Indonesia). p. 113-121.

Anonimous. 2001. Polymerase Chain Reaction (PCR) (A method for multiplying DNA). Aquatic stock Improvement Company, California: 4 pp.

Benzie, J.A.H., Ballment, E., Forbes, A.T., Dementriades, N.T., Sugama, K., Haryanti, $\&$ Moria, S.B. 2002. Mt DNA variation in IndoPacific populations of the giant tiger prawn, Penaeus monodon. Molecular Ecology, 11 : 2553-2569.

Benzie, J.A.H., Kenway, M., \& Trott, L. 1997. Estimates for The Heritability of Size in Juvenile $P$. monodon from Half-sib Mattings. Aquaculture, 152: 49-53.

Flegel, T.W. 2007. Construction of a genetic linkage map of the black tiger shrimp (Penaeus monodon) using AFLP, mikrosatelites and SNP markers. Genetic Computation Limited.

Goyard, E., Penet, L., Chim, L., Cuzon, G., Bureau, D., Bedier, E., \& Aquacop. 2002. Selective Breeding of The Tahitian Domesticated Population of Pacific Blue Shrimp (Litopenaeus stylirostris); Perspectives for the New Caledonian Shrimp Industry. World Aquaculture, 33(3): 28-70.

Haryanti, Permana, I.G.N., Wardana, I.K., Muzaki, A., and Fachrudin. 2007. Selective breeding of SPF (Specific Pathogen Free) traits of black tiger shrimp, Penaeus monodon on first generation F-1.Technical Reports of Research Institute for Mariculture, Gondol (In Indonesia). $11 \mathrm{pp}$.

Haryanti \& Sugama, K. 2007. Quality and Genetic improvement of shrimp. Paper colection of Aquaculture Research.
Symphosium Marine and Fisheries, Bidakara Hotel Jakarta, 7 August 2007 (In Indonesia) $8 \mathrm{pp}$.

Lightner, D.V. 2004. The Penaeid Shrimp Viral Pandemics due to IHHNV, WSSV, TSV and YHV: History in the Americas and Current Status. www.libnoaa/japan/aquaculture/ proceeding/report 32/lightner_corrected, $20 \mathrm{pp}$.

Moria, S.B., Haryanti, Permana, I.G.N., \& Sugama, K. 2002. Genetic marker on growth variability of black tiger shrimp, Penaeus monodon from different sources of spawner throught mt-DNA RFLP analysis. Indonesia Fish. Res. J., 8(5): 1-9.

Moria, S.B., Permana, I.G.N., \& Haryanti. 2003. Analysis of mt-DNA fry of black tiger shrimp, Penaeus monodon from different sources of spawner. Aquaculture Indonesia, 4(1):1927.

Ovenden, J.R. 2000. Development of restriction enzyme markers for red snapper (Lutjanus erythropterus and Lutjanus malabaricus) stock variation in mitochondrial DNA. Molecular Fisheries Laboratory. Southern Fisheries Centre. Produced for CSIRO Marine Laboratories as part of the ACIAR Indonesia Snapper Project.

Ramirez, D.A. 1991. Genetics. SEAMEO-SEARCA, UPLB. Philippines. 217 pp.

Sbordoni, V., De Mattthaeis, E. CobolliSbordoni, M., La Rosa, G., \& Mattoccia, M. 1987. Bottleneck Effects and The Depression of Genetic Variability in Hatchery Stocks of Penaeus japonicus (Crustacea:Decapoda). Aquaculture, 57: 239-251.

Sugama, K., Haryanti, Benzie, J.A.H., \& Ballment, E. 2002. Genetic variation and population of the giant tiger prawn, Penaeus monodon, in Indonesia. Aquaculture, 205: 37-48. 